\title{
Reproduction and feeding ecology of Amphisbaena munoai and Anops kingi (Amphisbaenia, Amphisbaenidae) in the Escudo Sul-Rio-Grandense, southern Brazil
}

\author{
Rafael L. Balestrin ${ }^{1} \&$ Lize H. Cappellari ${ }^{2}$
}

1. Laboratório de Herpetologia, Departamento de Zoologia, Instituto de Biociências, Universidade Federal do Rio Grande do Sul. Av. Bento Gonçalves, 9500, prédio 43435, 91501-970 Porto Alegre, RS, Brazil. (atractus@ hotmail.com)

2. Universidade da Região da Campanha, Rua General Osório, 522, 96570-000 Caçapava do Sul, RS, Brazil.

\begin{abstract}
This study presents original data on the reproduction and feeding ecology of two syntopic amphisbaenians, Amphisbaena munoai Klappenbach, 1969 and Anops kingi Bell, 1833, from southern Brazil. Sampling was carried out from April 2004 to April 2006 at a highland area located in São Jerônimo and Barão do Triunfo municipalities, Rio Grande do Sul, Brazil. A total of 647 amphisbaenians were collected, 510 specimens of A. munoai and 137 specimens of A. kingi, of which 130 and 93, respectively, had their gonads and gut content analyzed. Both species presented a unimodal pattern of seasonal distribution, sexually mature females with significantly larger snout vent length (SVL) than sexually mature males, and seasonal reproductive cycle. Adults of $A$. kingi had significantly larger (SVL) than those of Amphisbaena munoai. Both species had generalist diets, but termites (Isoptera) was a staple item in their diet. Greater predominance of insect larvae was observed in the diet of $A$. kingi, which may be due to its larger body in comparison to A. munoai. Insect larvae ingested by A. kingi were significantly larger than those ingested by A. munoai. Diets of adult males and females of both species were not significantly different. The ontogenetic diet comparison in both species revealed significant numerical differences, with adults consuming higher numbers of prey.
\end{abstract}

KEYWORDS. Seasonality, sexual dimorphism, diet.

RESUMO. Reprodução e ecologia alimentar de Amphisbaena munoai e Anops kingi (Amphisbaenia, Amphisbaenidae) no Escudo Sul-Rio-Grandense, sul do Brasil. O presente estudo fornece dados originais sobre a reprodução e ecologia alimentar de duas espécies sintópicas de Amphisbaenia, Amphisbaena munoai Klappenbach, 1969 e Anops kingi Bell, 1833, no sul do Brasil. As coletas foram realizadas entre abril de 2004 a abril de 2006, em uma área elevada, localizada entre os municípios de São Jerônimo e Barão do Triunfo, Rio Grande do Sul, Brasil. No total, 647 anfisbênios, 510 exemplares de A. munoai e 137 de A. kingi, foram encontrados ao longo do período amostral, e destes 130 e 93 respectivamente tiveram suas gônadas e conteúdo alimentar analisados. Ambas as espécies apresentaram padrão unimodal de distribuição sazonal, fêmeas sexualmente maduras com comprimento rostro cloacal (CRC) significativamente maior que o dos machos sexualmente maduros e ciclo reprodutivo sazonal. Adultos de A. kingi apresentaram (CRC) significativamente maior do que em adultos de Amphibaena munoai. As duas espécies apresentaram diversas categorias alimentares na composição de suas dietas, entretanto térmites (Isoptera) parecem compor um elemento base. Uma maior predominância de larvas de insetos foi observada na dieta de A. kingi em relação a A. munoai, o que pode estar relacionado ao maior tamanho do corpo da primeira espécie. Larvas de insetos ingeridas por A. kingi foram significativamente maiores do que aquelas ingeridas por A. munoai. Em ambas as espécies não foram encontradas diferenças significativas nas dietas de machos e fêmeas adultos, mas em uma comparação ontogenética, foram observadas diferenças significativas numéricas, sendo que adultos ingeriram um número maior de presas que juvenis.

PALAVRAS-CHAVE. Sazonalidade, dimorfismo sexual, dieta.

In general, available information about Squamata reptile ecology is highly biased for large or abundant species, with characteristics that make the study easier, such as diurnal and terrestrial species. Information relative to small and fossorial Squamata reptiles are very scarce (How \& SHINE, 1999). Neotropical amphisbaenians are a good example. Only for the Brazilian territory, a total of 57 species, in six genera, are described (MotT \& VIEITIS, 2009). This is one of the highest amphisbaenian diversity in the world ( $80 \%$ of South American species and 35\% of world species) (GANs, 2005) but the natural history of this group has been little explored (e.g. Barros Filho \& Valverde, 1996; Colli \& Zamboni, 1999; Andrade et al., 2006; BERNARDO-Silva et al., 2006). On the other hand, regions of temperate climate, mainly in North America, Europe and Australia, although less diverse, revealed Squamata reptile species that were good models for studies emphasizing natural history, related to the easy observation/capture and to the relative frequency (SEIGEL \& ColLins, 1993).
In the Brazilian territory, due to its large geographical abundance, several biome types can be found, most of them in the equatorial and tropical climates (Di-Bernardo et al., 2007). However, in southern Brazil, the Pampa biome is under the influence of the mesothermic temperate climate (IBGE, 1986; NIMER, 1989). The Pampa biome, although less diverse than most of the Brazilian biomes, presents species of Squamata reptiles that have been used as models in natural history studies (Maciel et al., 2003; Aguiar \& Di-Bernardo, 2004, 2005; Rufatto et al., 2003; Balestrin \& DiBeRnARdo, 2005; Balestrin et al., 2007; CAPPELlari et $a l ., 2007)$. Field expeditions to an elevated area in the state of Rio Grande do Sul (Escudo Sul-Rio-Grandense in the Pampa biome), revealed a high abundance of two sintopic amphisbaenian species, Amphisbaena munoai Klappenbach, 1969 and Anops kingi Bell, 1833. In addition to the easy capture, these species allowed good conditions to the implementation of studies focusing on their ecology and natural history. 
Amphisbaena munoai is a small sized species and poorly known species that also occurs in Uruguay (GANs, 2005). Information about the natural history of $A$. munoai was presented by BERNARDO-SILVA et al. (2006), who studied the diet of the species in an area close to where the present study was developed (Escudo Sul-RioGrandense). Nothing was known until now about the reproduction of this species.

Anops kingi is a little studied species in relation to its taxonomy and natural history. The reproduction of this species was described by VEGA (2001) in an area of temperate climate in Argentina.

In this work, data related to the reproduction and feeding ecology of A. munoai and A. kingi in the Escudo Sul-Rio-Grandense, southern Brazil are presented based on the analysis of fixed specimens and on field observations.

\section{MATERIAL AND METHODS}

All specimens came from São Jerônimo and Barão do Triunfo municipalities in the Escudo Sul-RioGrandense, Brazil (Fig. 1). The study area is composed of high lands (approximately $600 \mathrm{~m}$ ) with granite intrusions that form the Cinturão Móvel de Dom Feliciano formation (RAmBo, 2000), Southeastern Hills or Escudo Sul-Rio-Grandense. The vegetation is a mosaic represented by zones of transition of "thick" grasslands similar to the Savanna or to the Semidecidual Stational Forest (PorTo, 2002; QuAdros \& PILlar, 2002).

Mesothermic temperate climate, relatively homogenous, predominates in the region. Mean temperatures during the two years of the study were $22.0^{\circ} \mathrm{C}$ \pm 1.1 during summer and $13.9^{\circ} \mathrm{C} \pm 1.3$ during the winter. Monthly rainfall in the area varied from $42.4 \mathrm{~mm}^{3}$ to 202.2 $\mathrm{mm}^{3}(\bar{x}=113.7)$. (Instituto Nacional de Meteorologia Oitavo Distrito de Meteorologia Porto Alegre, for the closest municipality, Encruzilhada do Sul) (Fig. 2).

Fieldwork occurred between April 2004 and April 2008. During this time, the animals were found through active search in the study area, where possible shelters such as rocks, $\operatorname{logs}$ and burrows were inspected. Sampling effort was calculated by the sum of the total hours of each collector in active search activities. For every specimen found, information regarding date, time of day and habitat were noted. However, only a small portion of the animals found were captured for analysis of the gonads and stomach content.

All of the specimen captured were sacrificed on the spot, by a lethal injection. Specimens were weighted using a dynamometer (scale of $0.1 \mathrm{~g}$ ), and measured in the snout vent length (SVL), and tail length (TL) with a digital caliper (scale of $0.1 \mathrm{~mm}$ ). All specimens were deposited in the herpetological collection of the Museu de Ciências e Tecnologia da Pontifícia Universidade Católica do Rio Grande do Sul (MCT).

To estimate reproductive period, females and males were dissected, and the data were grouped by month of capture. Females were considered mature when had vitelogenic follicles with a size equal or larger than $4 \mathrm{~mm}$, for A. munoai, and $6 \mathrm{~mm}$, for $A$. kingi, or when they had eggs (SHINE, 1977, 1988). The highest length of the follicle or the egg of each species was measured with a digital caliper (scale of $0.1 \mathrm{~mm}$ ) for a posterior correlation with months of capture.

Males were considered mature when their deferent ducts were coiled (SHINE, 1988). The mean volume of the testicles was calculated using the formula of the volume of a elipsoid: $V=4 / 3 \pi \mathrm{ab} 2$, where $a$ is $1 / 2$ of the length of the longest axis and $b$ is $1 / 2$ of the largest width of the testis (REZENDE-PinTo et al., 2009).

To evaluate the variation throughout the year in the volume of the testicles, we removed the SVL effect on their volume. For that, we calculated the residuals of the regression between SVL and the volume of the testicles and performed an analysis of the monthly distribution of the adjusted volume of the adult testicles throughout the years of study (REZENDE-Pinto et al., 2009).

The litter size (fecundity) was estimated based on the number of vitelogenic follicles and eggs present in the female oviducts.

The diet was investigated by dissecting and analyzing the content found in the digestive tube of the collected specimens. A quantitative analysis was performed on the abundance and absolute frequency of food categories data. For this analysis, the number of items was counted in each stomach, and their longest length and width (when possible) were measured. Also, the sphere volume of each item was estimated using the equation described above for testicular volume. Whole insect larvae were measured in their longest length. The obtained values for each amphisbaenian species were compared using parametric (t-test) or non-parametric (Mann-Whitney) tests depending on the data distribution.

Prey diversity found in the stomachs was calculated using the Shannon-Wiener index (PIANKA, 1973): H'=- $\Sigma \mathrm{p}_{\mathrm{i}}$ $\log _{2}\left(\mathrm{p}_{\mathrm{i}}\right)$; with $\mathrm{p}_{\mathrm{i}}$ being the relative abundance of the prey taxon in the diet $\mathrm{i}$.

To determine the similarity degree between the diets of the two species, we used the similarity index $\mathrm{O}_{\mathrm{jk}}$ (adapted from KREBS, 2001):

$$
\begin{aligned}
& \mathrm{O}_{\mathrm{jk}}=\sum P_{i j} P_{i k} \\
& \sqrt{\sum \mathrm{P}_{\mathrm{ij}}{ }^{2} \sum \mathrm{P}^{2}{ }^{2}}
\end{aligned}
$$

where $\mathrm{P}_{\mathrm{ij}}$ and $\mathrm{P}_{\mathrm{ik}}$ are the proportion of food items in the category $\mathrm{i}$ in $\mathrm{j}$ and $\mathrm{k}$ groups. Similarity index values vary from zero (lack of similarity) to one (complete similarity).

To describe the relative importance of each type of item consumed, the importance value of the prey was calculated (GADSDEN \& PALACIOS-ORONA, 1997): V.I. $=\mathrm{V}{ }$ $+\mathrm{N}_{\mathrm{ij}}^{\prime}+\mathrm{F}_{\mathrm{ij}}^{\prime}$ where $\mathrm{V}_{\mathrm{ij}}^{\prime}=\mathrm{V}_{\mathrm{ij}} / \Sigma \mathrm{V}_{\mathrm{ij}} / \mathrm{N}_{\mathrm{ij}}=\mathrm{N}_{\mathrm{ij}} / \Sigma \mathrm{N}_{\mathrm{ij}} / \mathrm{F}_{\mathrm{ij}}^{\prime}=\mathrm{F}_{\mathrm{ij}} /$ $\Sigma \mathrm{N}_{\mathrm{j}}$. V.I. = importance value; $\mathrm{V}_{\mathrm{ij}}=$ volume of food item $\mathrm{i}$ in the predator $\mathrm{j} ; \Sigma \mathrm{V}_{\mathrm{ij}}=$ total volume of the stomach content; $\mathrm{N}_{\mathrm{ij}}=$ number of $\mathrm{i}$ elements of the food item in the predator $\mathrm{j} ; \Sigma \mathrm{N}_{\mathrm{ij}}=$ total number of prey in the sample; $\mathrm{F}_{\mathrm{ij}}=$ number of stomach contents where the food item $\mathrm{i}$ of the predator $\mathrm{j}$ is found; $\mathrm{N}_{\mathrm{j}}=$ total number of stomachs of predator $\mathrm{j}$.

To compare size between adult male and females, SVL values and the relative length of TL (TL/SVL) were initially tested in relation to normality (KolmogorovSmirnov test) and homocedasticity (Levene test), and then were compared using the t-Student test or Mann 
Whitney, when appropriate. All these statistical tests were performed using the computer program SPSS 10.

Examined samples: Amphisbaena munoai: BRASIL, Rio Grande do Sul: São Jerônimo $\left(30^{\circ} 22^{\prime}\right.$ S, $\left.51^{\circ} 54^{\prime} \mathrm{W}\right), 8$, $40^{\circ}$ 17.IV.2004, R. L. Balestrin, W. Vaz \& A. P. Santos Jr. cols. (MCP 14893, 14915, 14916, 14918-14926); 49, 40 15.V.2004, R. L. Balestrin \& A. Guedes cols. (MCP 14978, 14980-14985, 14987); 5, 70', 20.VI.2004, R. L. Balestrin \& L. H. Cappellari cols. (MCP 15029, 15030, 15032, 15034, 15035, 15037-15043); 2q, $60^{7}$, 6.VII.2004, R. L. Balestrin \& L. H. Cappellari cols. (MCP 15111, 15113-15115, 15117-15120 ); 3, 30', 20.VII.2004, R. L. Balestrin, L. H. Cappellari \& A. P. Santos Jr. cols. (MCP 15121-15123, 15125-15127); 29, 30', 25.VIII.2004, R. L.
Balestrin, L. H. Cappellari \& A. P. Santos Jr. cols (MCP 1535015352, 15355, 15356); 8, 80', 17.IX.2004, R. L. Balestrin \& J. G. Frota cols. (MCP 15409-15421, 15423-15425); 3우 60", 28.X.2004, R. L. Balestrin, L. H. Cappellari \& W. Vaz cols. (MCP 15627-15630, 15632-15636), 5ㅇ, 50', 28.XI.2004, R. L. Balestrin, L. H. Cappellari, C. Zank \& M. Di-Bernardo cols. (MCP 15784-15793); 69, 50', 12.XII.2004, R. L. Balestrin \& L.

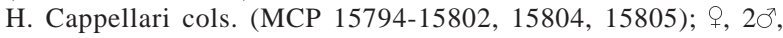
28.I.2005, R. L. Balestrin, L. H. Cappellari, A. P. Santos Jr. \& F. Bonfiglio cols. (MCP 15854, 15856, 15890); 3ㅇ, ơ, 22.II.2005, R. L. Balestrin, L. H. Cappellari, A. P. Santos Jr. \& F. Bonfiglio cols (MCP 15961-15963, 15967); 29, 207, 28.III.2005, R. L. Balestrin \& L. H. Cappellari cols. (MCP 15957, 15958, 15960 , 15966); 3, 30 , 17.IV.2005, R. L. Balestrin, L. H. Cappellari \& A. P. Santos Jr. cols. (MCP 16190-16192, 16194-16196), O
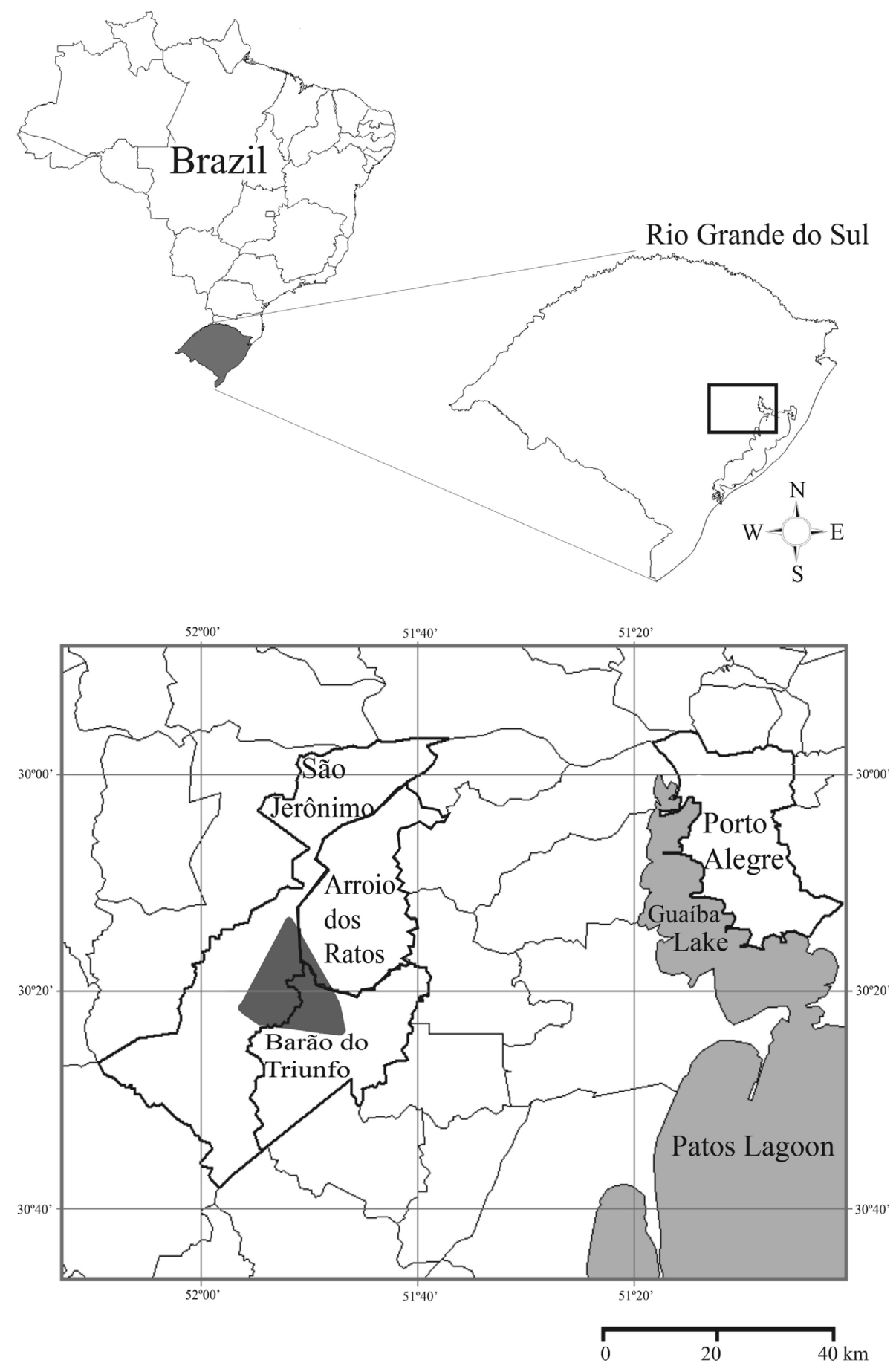

Figure 1. Location of the study area (dark grey) between São Jerônimo and Barão do Triunfo municipalities, Southern Brazil. 
25.V.2005, R. L. Balestrin, L. H. Cappellari \& A. P. Santos Jr. cols. (MCP 16200); , 25.VI.2005, R. L. Balestrin \& T. Lema cols. (MCP 16197); 20, 14.VII.2005, R. L. Balestrin, L. H. Cappellari \& A. P. Santos Jr. cols. (MCP 16738, 16740); 29, 20', 24.VIII.2005, R. L. Balestrin, A. P. Santos Jr. \& C. Zank cols. (MCP 16783, 16784, 16786, 16787); ㅇ, 20', 26.IX.2005, R. L. Balestrin, L. H. Cappellari \& F. Bonfiglio cols (MCP 17785, 17787, 17790); 29, 20', 26.XI.2005, R. L. Balestrin, F. Bonfiglio \& A. P. Santos Jr. cols. (MCP 17746, 17786, 17788, 17789); O', 23.III.2006, R. L. Balestrin, L. H. Cappellari \& A. P. Santos Jr. cols. (MCP 17963). Anops kingi: BRASIL, Rio Grande do Sul: São Jerônimo $\left(30^{\circ} 22^{\prime}\right.$ S, $\left.51^{\circ} 54^{\prime} \mathrm{W}\right), 3$, $1^{*}$, 17.IV.2004, R.L. Balestrin \& W. Vaz cols (MCP 14891, 14902, 14907, 14908); 우 $80^{*}, 1 *$, 16.V.2004, R. L. Balestrin, L. H. Cappellari \& A. P. Santos Jr. cols. (MCP 14968-14977); 10, 20', 19.VI.2004, R. L. Balestrin \& L. H. Cappellari cols. (MCP 15048-15054, 1505615060); 4ㅇ, 3o , 06.VII.2004, R. L. Balestrin \& L. H. Cappellari cols. (MCP 15095-15101); 5, 50’, 20.VII.2004, R. L. Balestrin, L. H. Cappellari \& A. P. Santos Jr. cols. (MCP 15102-15110); 49, 30', 1* 28.VIII.2004, R. L. Balestrin \& L. H. Cappellari cols. (MCP 15336-15343); 5ㅇ, 30', 18.IX.2004, R. L. Balestrin, L. H. Cappellari \& J. Frota cols. (MCP 15399-15402, 15404-15406, 15408); 39, 11.X.2004, R. L. Balestrin, L. H. Cappellari \& A.P. Santos Jr. cols (MCP 15637, 15638); 1ㅇ, 23.XI.2004, R. L. Balestrin, L. H. Cappellari \& A. P. Santos Jr. cols. (MCP 15779); 1*, 26.I.2005, R. L. Balestrin, L. H. Cappellari \& A. P. Santos Jr. cols. (MCP 15859); 20', 25.V.2005, R. L. Balestrin, L. H. Cappellari \& A. P. Santos Jr. cols. (MCP 16185, 16189); 49, 30', $1 *$, 28.VI.2005, R. L. Balestrin, L. H. Cappellari \& A. P. Santos Jr. cols. (MCP 16177-16179, 16181, 16183, 16184, 16187, 16188); 29, 30', 14.VII.2005, R. L. Balestrin, L. H. Cappellari \& A. P. Santos Jr. cols (MCP 16724, 16725, 16727, 16728, 16730); 4ㅇ, 50', 27.IX.2005, R. L. Balestrin, L. H. Cappellari \& A. P. Santos Jr. cols. (MCP 17770, 17774-17779, 17783, 17784); 39 , ơ, 1*, 24.X.2005, R. L. Balestrin, L. H. Cappellari \& A. P Santos Jr. cols. (MCP 17771, 17772, 17780-17782) (*, juveniles).

\section{RESULTS}

Seasonal Activity. A total of 1,385.8 hours/collector of capture effort was performed in the 25 months of visual search in the study area. A total of 647 amphisbaenians were collected, 510 specimens of Amphisbaena munoai and 137 specimens of Anops kingi at a capture rate of 0.37 and 0.10 specimen/hour/collector, respectively. For both species, all individuals were found during the day in areas of rocky grasslands. All specimens were found under stones, except three A. munoai under decomposing barks.

Amphisbaena munoai was sampled throughout the year with the highest number of captures recorded

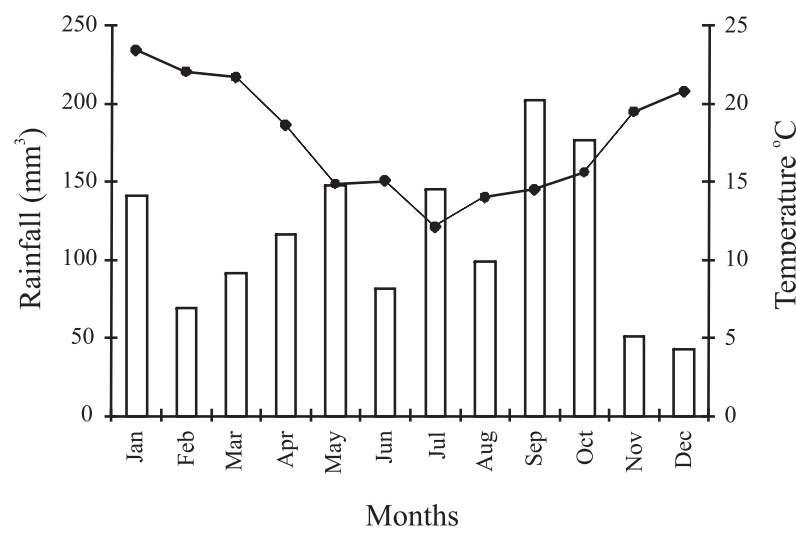

Figure 2. Monthly mean temperature and rainfall in Encruzilhada do Sul municipality (Escudo Sul-Rio-Grandense), southern Brazil, between April 2004 and April 2006. (bars, rainfall; line, temperature). between May and October (0.74 specimens/hour/ collector) with a peak in September (0.94 specimen/hour/ collector). In the warmest months of the year, from November to March, the number of encounters decreased (0.10 specimen/hour/collector (Fig. 3).

Individuals of Anops kingi were collected in January (only one specimen) and from April to November. Highest capture rates were recorded from June to September ( 0.3 specimen/hour/collector). In months with high mean temperatures, from November to April, capture rate was much lower (0.004 specimen/hour/collector). No specimen was found in December, February, and March (Fig. 3).

Body size and sexual dimorphism. A total of 130 specimens of Amphisbaena munoai (61 females and 69 males) were analyzed. Mature females of A. munoai measured from $123 \mathrm{~mm}$ to $142 \mathrm{~mm}$ of SVL $(\bar{x}=130.36 \pm$ $4.79 ; \mathrm{n}=42)$ and from $13 \mathrm{~mm}$ to $20 \mathrm{~mm}$ of TL $(\bar{x}=15.42 \pm$ $1.20 ; \mathrm{n}=36)$. Mature males measured between $102 \mathrm{~mm}$ and $137 \mathrm{~mm}$ of SVL $(\bar{x}=120.53 \pm 7.38 ; \mathrm{n}=62)$ and between $12 \mathrm{~mm}$ and $17 \mathrm{~mm}$ of TL $(\bar{x}=15.04 \pm 1.18 ; \mathrm{n}=$ 56). The SVL of the mature females was significantly higher than the SVL of mature males (Mann-Whitney; $p<0.001$ ) and the relative length of TL of males was significantly higher than the TL for the females (Mann-Whitney; $\mathrm{p}<$ 0.05 ; or t-test: $\mathrm{p}<0.05$ ).

A total of 93 specimens of Anops kingi (49 females, 38 males) were analyzed. Mature females measured between $206 \mathrm{~mm}$ and $242 \mathrm{~mm}$ of SVL $(\bar{x}=218.69 \pm 9.59$; $\mathrm{n}=26)$ and from $21 \mathrm{~mm}$ to $29 \mathrm{~mm}$ of TL ( $\bar{x}=25.88 \pm 1.90$; $\mathrm{n}=25$ ). Mature males measured from $163 \mathrm{~mm}$ to $220 \mathrm{~mm}$ of $\operatorname{SVL}(\bar{x}=195.04 \pm 16.29 ; \mathrm{n}=26)$ and between $19 \mathrm{~mm}$ and $26 \mathrm{~mm}$ of TL $(\bar{x}=22.26 \pm 2.3 ; \mathrm{n}=25)$. SVL of mature females was significantly higher than the SVL of mature males (Mann-Whitney; p < 0.001) and there was no significant difference in the relative length of TL between sexes (Mann-Whitney; $\mathrm{p}=0.2$; or t-test: $\mathrm{p}=0.3$ ).

Adults of $A$. kingi presented a SVL significantly higher than the adults of $A$. munoai, in males (MannWhitney; $\mathrm{p}<0.001 ; \mathrm{n}=130$ ) and females (Mann-Whitney; $\mathrm{p}<0.001 ; \mathrm{n}=68$ ).

Reproductive cycle, fecundity, and biometry of the eggs. The reproductive activity of the females of

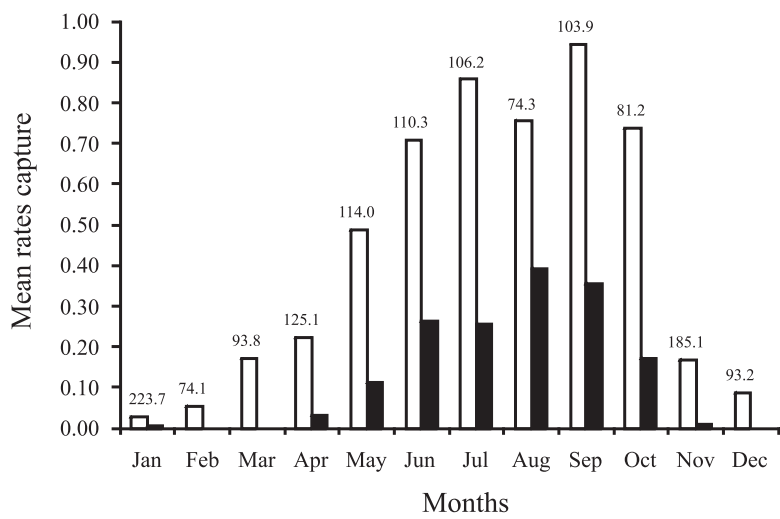

Figure 3. Mean rates of monthly captures of Amphisbaena munoai Klappenbach, 1969 (white bars) and Anops kingi Bell, 1833 (black bars) between April 2004 and April 2006 in Escudo Sul-Rio-Grandense the southern Brazil. Capture rates are presented as specimen/hourcollector. Values on the bars represent sample effort (hour-collector). 
Amphisbaena munoai began at the end of June and finished in December (Fig. 4). Vitelogenic follicles were found in June, August, September, and October and ovigerous females were found in November and December. In males, the mean adjusted volume of the testicles varied throughout the year, with highest values occurring in September and October (Fig. 5). The fecundity of A. munoai was low with litters of 1 or 2 eggs $(\bar{x}=1.8 \pm 0.46 ; \mathrm{n}=14)$, which are relatively long when compared with the SVL of the females (mean length 17.75 $\mathrm{mm} \pm 2.96 ; \mathrm{n}=14$ ). When in pairs, the eggs were disposed in lines inside the females' body.

Females of A. kingi presented vitelogenic follicles from June to October, with the only ovigerous female captured in November (Fig. 6), carrying two eggs disposed aligned in the oviduct. Individually, the eggs are relatively long (largest egg with $27.59 \mathrm{~mm}$ ) when compared with the SVL of the female $(215 \mathrm{~mm})$. It was not possible to observe the variation in the mean adjusted value of the testicles throughout the months of capture.

Diet. From a total of 130 dissected stomachs of $A$. munoai, 31 (13 males, 8 females, and 10 juveniles) had prey items. Seven food categories were identified (Isoptera, eggs of Isoptera, Formicidae, Coleoptera larvae,

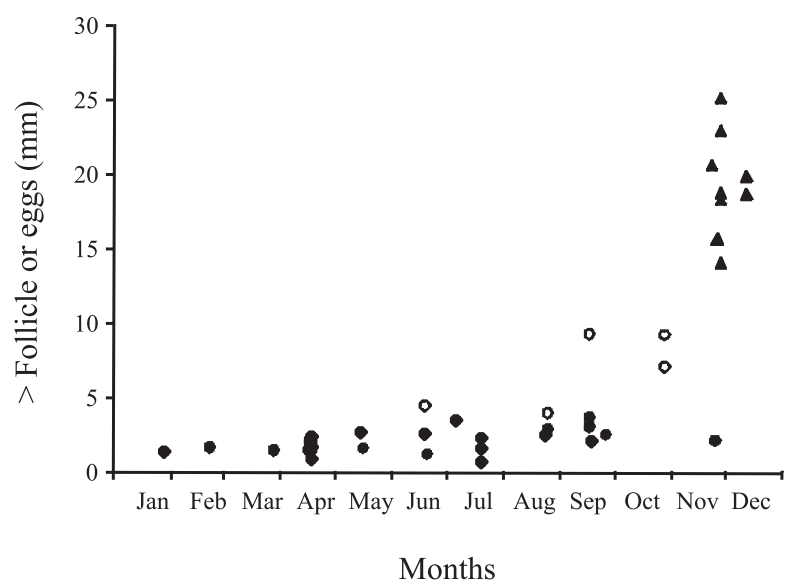

Figure 4. Seasonal distribution of the length (in $\mathrm{mm}$ ) of the largest follicle (closed circles, primary follicles; open circles, vitelogenic follicles) or eggs (triangles) of mature females of Amphisbaena munoai Klappenbach, 1969 in southern Brazil.

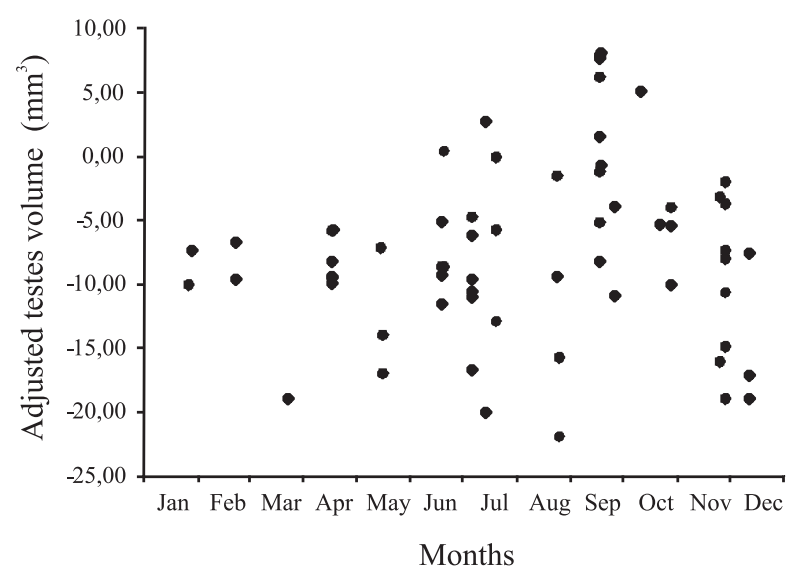

Figure 5. Seasonal distribution of the adjusted mean volume $\left(\mathrm{mm}^{3}\right)$ of the testicles of adult males of Amphisbaena munoai Klappenbach, 1969 in southern Brazil.
Diptera larvae, Lepidoptera larvae and Hirudinea), the majority arthropods, and also hirudineans. Isoptera was the most frequent item (83.9\% of the stomachs), with the highest number $(86.1 \%)$ and volume $(65.8 \%)$ of total preys (Tab. I). Hirudineans and lepidopteran larvae are the second most frequent identified item in the diet of $A$. munoai, each present, in $9.7 \%$ of the filled up stomachs. Numerically, the second most representative identified item was Diptera larvae (10.8\%), and volumetrically was Hirudina (6.7\%).The item with the most important value in the $\operatorname{diet}$ of $A$. munoai was Isoptera (V.I. $=2.52$ ), independent of sex and age class (males V.I. $=2.63$, females V.I. $=1.87$ and juveniles, independently of the sex VI = 2.69).

The maximum number of preys found in a stomach of Amphisbaena munoai was 45 ( $\bar{x}=13.68 \pm 10.74)$. The mean diversity of preys found per stomach was of $1.16 \pm$ 0.37 and the maximum richness found in a stomach was two food categories. The number of consumed preys by adult males $(\bar{x}=12.46 \pm 9.40)$ was not significantly different from the number of prey consumed by adult females $(\bar{x}=8.75 \pm 7.17)$ (t-test; $\mathrm{p}=0.35)$. The mean volume of the prey consumed by adult males $(\bar{x}=34.64$ $\pm 31.03 \mathrm{~mm}^{3}$ ) was not significant different from the mean volume of the prey consumed by adult females $(\bar{x}=19.28$ $\left.\pm 15.32 \mathrm{~mm}^{3}\right)$ (Mann Whitney; $\left.\mathrm{p}=0.469\right)$. When adults are compared with juveniles, independent of the sex, it was observed that the number of consumed preys by adults ( $\bar{x}=28.79 \pm 26.80$ ) was significantly higher than the number of prey consumed by juveniles $\bar{x}=19.20 \pm 13.0)$ ( $\mathrm{t}$-test; $\mathrm{p}=0.046)$. On the other hand, the mean prey volume consumed by adults $\left(\bar{x}=28.79 \pm 26.83 \mathrm{~mm}^{3}\right.$ ), was not significantly different from the mean volume consumed by juveniles $\left(\bar{x}=24.50 \pm 36.23 \mathrm{~mm}^{3}\right)(\mathrm{t}$-test; $\mathrm{p}=0.713)$.

The trophic diversity was higher in the diet of the adult females $\left(\mathrm{H}^{\prime}=1.27\right)$ in comparison with juveniles $\left(\mathrm{H}^{\prime}\right.$ $=0.67)$ and adult males $\left(H^{\prime}=0.30\right)$.

From a total of 93 dissected individuals of Anops kingi, 71 stomachs ( 38 females, 19 males, and 14 juveniles) presented 11 different food categories, mostly arthropods, and in less proportion hirudineans.

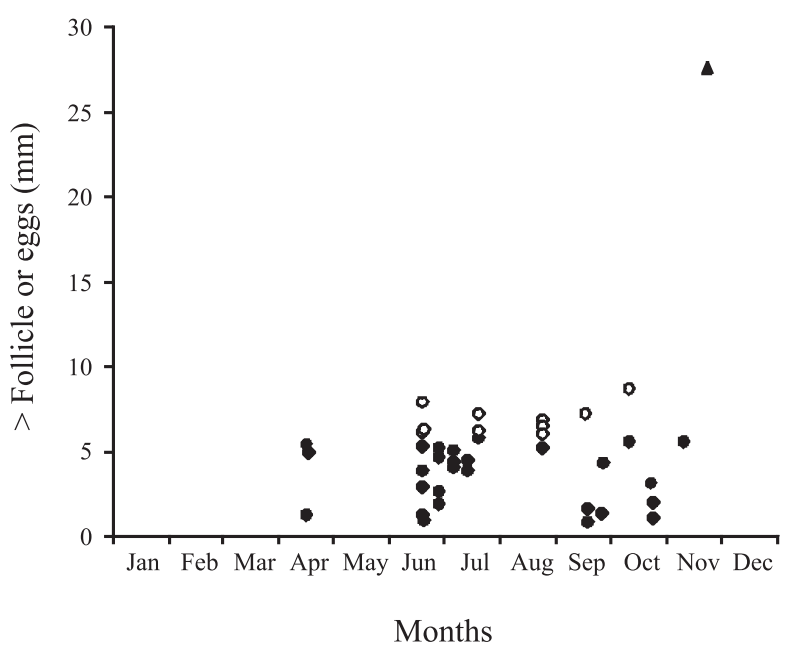

Figure 6. Seasonal distribution of the length (in $\mathrm{mm}$ ) of the largest follicle (close circles, primary follicles; and open circles, vitelogenic follicles) or egg (triangles) of mature females of Anops kingi Bell, 1830 in southern Brazil. 
Table I. Number (N), volume (in $\left.\mathrm{mm}^{3}\right)(\mathrm{V})$, frequency (F), and importance value (VI) of the prey in the diet of Amphisbaena munoai Klappenbach, 1969 and Anops kingi Bell, 1833 in Escudo Sul-Rio-Grandense, southern Brazil (NIA, non-identified arthropods).

\begin{tabular}{|c|c|c|c|c|c|c|c|c|}
\hline \multirow[b]{2}{*}{ Item } & \multicolumn{4}{|c|}{ Amphisbaena munoai } & \multicolumn{4}{|c|}{ Anops kingi } \\
\hline & $\mathrm{N}(\%)$ & $\mathrm{V}(\%)$ & $\mathrm{F}(\%)$ & VI & $\mathrm{N}(\%)$ & $\mathrm{V}(\%)$ & $\mathrm{F}(\%)$ & VI \\
\hline \multicolumn{9}{|l|}{ Insecta } \\
\hline Blattodea & & & & & $1(0.1)$ & $9.07(0.1)$ & $1(1.4)$ & 0.02 \\
\hline Coleoptera & & & & & $4(0.3)$ & $62.82(0.4)$ & $4(5.5)$ & 0.02 \\
\hline Coleoptera larvae & $2(0.5)$ & $10.13(1.3)$ & $2(6.5)$ & 0.08 & $77(5.9)$ & $2337.99(13.4)$ & $39(54.9)$ & 0.85 \\
\hline Diptera Larvae & $46(10.8)$ & $12.11(1.5)$ & $2(6.5)$ & 0.19 & $6(0.5)$ & $28.48(0.2)$ & $3(4.2)$ & 0.07 \\
\hline \multicolumn{9}{|l|}{ Hymenoptera } \\
\hline Formicidae & $1(0.2)$ & $0.29(0)$ & $1(3.2)$ & 0.04 & $22(1.7)$ & $19.71(0.1)$ & $6(8.5)$ & 0.10 \\
\hline Hemiptera & & & & & $1(0.1)$ & $0.73(0)$ & $1(1.4)$ & 0.01 \\
\hline Lepidoptera larvae & $3(0.7)$ & $32.46(4.1)$ & $3(9.7)$ & 0.29 & $1(0.1)$ & $13.81(0.1)$ & $1(1.4)$ & 0.05 \\
\hline Isoptera & $365(86.1)$ & $526.83(65.8)$ & $26(83.9)$ & 2.52 & $1140(86.6)$ & $3230.58(18.5)$ & $39(54.9)$ & 3.98 \\
\hline Eggs of Isoptera & $2(0.5)$ & $8.95(1.1)$ & $1(3.2)$ & 0.05 & $16(1.2)$ & $66.84(0.4)$ & $2(2.8)$ & 0.05 \\
\hline Unidentified larvae & & & & & $21(1.6)$ & $650.09(3.7)$ & $6(8.5)$ & 0.17 \\
\hline NIA & & $156.45(19.5)$ & $12(38.7)$ & & & $7419.90(42.6)$ & $47(66.2)$ & \\
\hline Hirudinea & $5(1.2)$ & $53.42(6.7)$ & $3(9.7)$ & & $27(2.1)$ & $3353.53(19.2)$ & $7(9.9)$ & 0.46 \\
\hline Plant material & & & & & & $227.69(0.3)$ & & \\
\hline Stones & & $0.62(0.1)$ & $1(3.2)$ & 0.19 & & $10.93(0.1)$ & & \\
\hline TOTAL & 424 & 801.26 & & & 1316 & $17,193.55$ & & \\
\hline
\end{tabular}

Isopterans and coleopteran larvae were the most frequent identified items, each one present in $54.9 \%$ of the stomachs with food content. The second most frequent identified item was Hirudinea, present in $9.9 \%$ of the stomachs with contents. The most numerically representative item was Isoptera, which corresponded to $86.6 \%$ of the total sampled items (Tab. I). The second most represented item was coleopteran larvae, which corresponded to $5.9 \%$ of the total sampled items. Volumetrically, the most representative item was Hirudinea with $19.2 \%$ of the total volume of sampled preys. The second item was Isoptera, with $18.5 \%$ of the total volume of the prey. When analyzed together, insect larvae are the most frequent item $(63.4 \%)$, the second item in terms of number $(7.8 \%)$, and the third item in terms of volume $(31 \%)$. The calculation of the importance value of food items showed that the most important item in the diet of $A$. kingi was Isoptera (V.I. $=3.98$ ) independent of sex and age class (males V.I. $=2.21$, females V.I. $=1.52$, and juveniles independent of sex V.I. $=1.55$ ).

The maximum number of preys found in a stomach of $A$. kingi was 131 ( $\bar{x}=18.59 \pm 28.57$ ). The mean diversity of preys found per stomach was $1.48 \pm 0.69$ and the highest richness found in one stomach was four. The number of preys consumed by adult males $(\bar{x}=24.31 \pm 33.70)$ was not significantly different from the number of preys consumed by adult females ( $\bar{x}=17.45 \pm 26.60$ ) (Mann Whitney; $\mathrm{p}=0.472$ ). Accordingly, it was not observed a significant difference between the volume of ingested prey by males $\left(\bar{x}=278.23 \pm 318.49 \mathrm{~mm}^{3}\right)$ and adult females $\left(\bar{x}=247.75 \pm 201.25 \mathrm{~mm}^{3}\right)($ Mann Whitney; $\mathrm{p}=0.240)$. Comparison between adults $(\bar{x}=20.23 \pm 29.62)$ and juveniles $(\bar{x}=3.57 \pm 4.27)$, independent of sex, shows a significant difference between the number of ingested preys (Mann Whitney; $\mathrm{p}<0.05$ ). However, it was not observed a significant difference in the volume of the prey ingested by adults $\left(\bar{x}=254.74 \pm 265.64 \mathrm{~mm}^{3}\right)$ and juveniles $\left(\bar{x}=227.52 \pm 348.08 \mathrm{~mm}^{3}\right)($ Mann Whitney; $\mathrm{p}=$ 0.103).
Trophic diversity was higher in the adult females $\operatorname{diet}\left(\mathrm{H}^{\prime}=1.15\right)$ and juveniles $\left(\mathrm{H}^{\prime}=1.15\right)$ in comparison with adult males $\left(\mathrm{H}^{\prime}=0.43\right)$.

Anops kingi and A. munoai are very similar in prey category in terms of numbers $\left(\mathrm{O}_{\mathrm{jk}}=0.99\right)$, but very different in terms of volume $\left(\mathrm{O}_{\mathrm{jk}}=0.68\right)$. Anops kingi presents a higher trophic diversity $\left(\mathrm{H}^{\prime}=0.89\right)$ in comparison to $A$. munoai $\left(\mathrm{H}^{\prime}=0.75\right)$. Isoptera is the item with highest importance value for both species (A. kingi V.I. = 3.98; $A$. munoai V.I. = 2.52), however, insect larvae and hirudineans were more frequent and had a higher importance value in the diet of $A$. kingi (V.I. $=1.02$ and 0.46 respectively) in comparison to $A$. munoai (VI $=0.43$ and 0.19 respectively). Insect larvae ingested by $A$. kingi $(\bar{x}=8.95 \pm 4.21 ; \mathrm{n}=23$ ) were significantly larger (Mann Whitney; $\mathrm{p}<0.001$ ) than larvae ingested by $A$. munoai $(\bar{x}=3.07 \pm 1.37 ; \mathrm{n}=51)$.

\section{DISCUSSION}

Seasonality. All 510 captured specimens of Amphisbaena munoai and 137 captured specimens of Anops kingi were found hiding only under decomposing barks but almost totally under stones. Amphisbaenians could get heat from the rocks to enhance their body temperature without exposing themselves to the ground surface, diminishing the predation risk (MARTín et al. 1990, 1991; LóPEZ et al. 1998).

Both species presented a uni-modal pattern of seasonal distribution, with highest capture rates between May and October for A. munoai, and from June to September for A. kingi. In the warmest months of the year (December to March) there was a decrease in the capture rate for both species. This seasonal distribution pattern may be explained, at least in part, by two nonexcluding hypothesis. The first one states that $A$. munoai and $A$. king $i$ would migrate vertically in the soil among the fresh and deep areas below the surface during summer, and in warm areas close to the surface during the winter, 
searching for an optimum body temperature. This hypothesis was proposed for A. kingi in central-east Argentina (VEGA, 2001), for Blanus cinereus (Vandelli, 1797) in an area of temperate climate in Spain (MarTín et al., 1990; LóPEZ et al., 1998), and for a fossorial snake Atractus reticulatus Boulenger, 1885 in an area close to the area of the present study in southern Brazil (BALESTRIN et al., 2007). However, studies on the physiology and habits of each species, as well as on the specific conditions of the soil involved, would be necessary for a better assessment of this hypothesis. The second hypothesis states that $A$. munoai and $A$. kingi could reach their preferable temperature by actively selecting rocks with different thickness, at different hours of the day (Civantus et al., 2003): thinner and easily warming during the winter, and thick and very difficult to warm during summer (López et al., 1998). The study area is composed by rocky grasslands that form the Cinturão Móvel de Dom Feliciano or Escudo Sul-Rio-Grandense. In this area, during summer, the activity of $A$. munoai and $A$. king $i$ would occur under thick rocks, probably chosen due to the high environmental temperatures. Probably, these rocks would not be lift during active search, which limited the collection method applied to the animals. At least in part this fact explains the low capture rate observed in the warmest months of the year. During the months of lower temperatures, A. munoai and A. kingi would hide under small rocks, which made their collection easier. The selection of rocks to regulate the body temperature was verified for B. cinereus (LóPEz et al., 1998) and Trogonophis wiegimanni Kaup, 1830, which select rocks when thermal properties are appropriate to keep the preferred body temperature (LóPEZ et al., 2002; Civantus et al., 2003).

In the same area and period in which the present study was carried out, a similar seasonal distribution pattern was observed for Amphisbaena trachura Cope, $1885(\mathrm{n}=7)$ and small snakes with terrestrial and fossorial habits, such as, Leptothyphlops munoai Orejas-Miranda, $1961(\mathrm{n}=8)$, Elapomorphus sp. (Wiegmann, 1843) $(\mathrm{n}=15)$, Pseudablabes agassizii (Jan, 1863) $(\mathrm{n}=11)$, and Taeniophallus occipitalis (Jan, 1863) ( $\mathrm{n}=13)$ (Rafael L. Balestrin pers. obs.).

Body size and sexual dimorphism. Sexually mature females of A. munoai and A. kingi reached a SVL size significantly larger than sexually mature males. In a population of A. kingi in Argentina, VeGA (2001) also found females with a SVL significantly larger than males. Amphisbaenian females with a SVL larger than males are reported for Zygaspis quadrifrons (Peters, 1862) (WевB et al., 2000) in southern Africa, and Amphisbaena alba Linnaeus, 1758 (Colli \& ZAMBONI, 1999), in Brazilian Cerrado. In several groups of Squamata, especially snakes, natural selection may favor a large body size in females that have an elevate reproductive cost (BONNET et al., 1998). In oviparous reptiles, the eggs represent the most part of the reproductive investment of the females, and large eggs represent a huge investment (SINERVO, 1993). Although they present a low fecundity, A. munoai and $A$. kingi seem to belong to this category because they have litters composed by large eggs in comparison to the female's body. This confort suggests a huge reproductive investment in the size of the eggs produced in each clutch. In fact, in general parameters the reproduction of amphisbaenids is characterized by small clutches composed by large eggs in relation to the female body size (ANDRADE et al., 2006). The size, shape, and number of eggs per clutch may be related to the fossorial habit of these animals (see egg fecundity and biometry). In addition, large eggs originate large juveniles, possibly leading to a lower mortality rate of the juveniles and a rapid maturation, compensating, in part, for the low fecundity observed for both species.

Amphisbaena munoai adult males presented significantly larger tails than adult females. This pattern may be related to the males' need of stowing their hemipenis'. It was not observed a sexual dimorphism in tail size in $A$. kingi which may be related to the defense behavior of the species. Although the A. munoai posses the ability to autotomize their tails, this did not occur during any of the captures in which the animal was held by its tail. This occurred frequently with the $A$. kingi (R. L. Balestrin pers. obs.). More comprehensive studies that investigate the ability to autotomize in other species may reveal differences in this characteristic.

Reproductive cycle, fecundity, and biometry of the eggs. In the present study Amphisbaena munoai presented a strictly seasonal reproductive cycle, with vitelogenesis occurring from June to October, ovigerous females from November to December, and recruitment in the warmest months of the year. In males the mean volume of the testicles presented a pattern of seasonal distribution, with high values between June and September, at the same time of the vitelogenic period of the females. Based on the highest adjusted volume of the testicles in September, vitelogenic follicles with maximum volumes between September and October, and production of eggs in December, it is inferred that, possibly that copula occurs between September and November.

Data also indicate a seasonal reproductive cycle for A. kingi, with females presenting vitelogenic follicles from June to October and ovigerous female in November. In Argentina, females of A. kingi also presented a seasonal reproductive cycle with vitelogenic follicles from July to December and eggs in September (Vega, 2001). The seasonality observed in the reproductive cycle of both species agrees with the observed for all scaled reptiles that had their reproductive cycles studied in southern Brazil, and with the pattern observed for these reptiles in temperate regions (DI-BERNARDO et al., 2007).

For the majority of species of amphisbaenians studied by now, the reproduction seemed synchronized with the warm and rainy seasons, varying with latitude, where species of low latitudes would have a longer reproductive cycle in comparison with species of high latitudes (ANDRADE et al., 2006; VEGA, 2001).

The low fecundity observed in A. munoai (1.8 eggs per clutch) and A. kingi (2 eggs per clutch) in the study area and in VEGA's work (2001) (A. kingi; 2.2 eggs per clutch), may be related to the small size of the adults. The low fecundity, in terms of number of eggs per clutch, occurs in the majority of species of amphisbaenians for which there are available data. However, species with 
larger SVL, such as Amphisbaena alba Linnaeus, 1758 (8 eggs) and Leposternon microcephalum Wagler, 1824 (6 eggs), may lay a higher number of eggs per clutch (ANDRADE et al. 2006). Clutches of A. munoai and A. kingi are composed by extremely elongated eggs that are arranged in line, occupying a large portion of female's body. Shape and arrangement of the eggs seem to be a shared characteristic among the majority of species of amphisbaenians studied until now. Probably, this characteristic helps the pregnant females to fit in the galleries under the soil (ANDRADE et al., 2006). Clutches with a similar pattern (small, having elongated eggs) could be observed in other groups of scaled fossorial reptiles, such as snakes (BALESTRIN \& Di-BERnARDo, 2005).

Diet. From 130 analyzed stomachs of A. munoai, only 31 presented some kind of content. BERNARDO-SILVA et al. (2006) recorded for the same species a high frequency of specimens with stomach contents (40 specimens out of 66 analyzed). Although there is a difference in individual frequency with stomach contents between the two populations, these were very similar in the composition of their diets. Undoubtedly, Isoptera was the main food item for both populations being a basic element in the diet of this species, independently of sex or age class.

Isoptera was also the item with the highest importance value in the diet of $A$. kingi, independently of age class and sex. This item was cited as the main food category in the diet of several species of neotropical amphisbaenians, such as Amphisbaena alba (CoLli \& ZAmboni, 1999), Amphisbaena darwinii heterozonata Burmeister, 1861 (CABrera \& Merlini, 1990), Amphisbaena mertensii Strauch, 1881 (CRUZ-NETO \& ABE, 1993), Amphisbaena munoai (BERNARDO-SILVA et al. 2006), as well as the African species Monopeltis anchietae (Bocage, 1873) and Zygapsus quadrifrons (WEBB et al., 2000), being potential preys in the amphisbaenian diets (BEEB, 1945, Duelmann, 1978). Isopterans may be among the prey types most abundant and available in the environment, and with adequate size, since amphisbaenians have a mouth aperture, in proportion, smaller than several reptiles (BERNARDO-SILVA et al., 2006). The capture of small and gregarious prey may occur without energy cost, since the predator generally attacks social insects when they are available in large amounts. This relationship was suggested for some lizard species which have isopterans as essential elements in their diets (Teixeira \& Giovanelli, 1999; CAPPellari et al., 2007). BernARdo-Silva et al. (2006) cite the possibility of $A$. munoai living inside termite and ant nests, as suggested for A. alba and Amphisbaena mitchelii Procter, 1923 (Azevedo-Ramos \& Moutinho, 1994). In Escudo Sul-RioGrandense the great majority of specimens of $A$. munoai and $A$. kingi, were collected under stones, generally associated with isopterans nests.

Ants are another example of small gregarious prey easily available in the environment, which eventually appear in the diet of Amphisbaena munoai and Anops kingi (VEGA, 2001; Bernardo-Silva et al., 2006). WeBB et al. (2000) studied the diets of the species M. anchietae and $Z$. quadrifrons and found ingestion proportions of termites and ants similar to the observed in the diet of $A$. munoai and $A$. kingi in the present study. These authors suggest that the low frequency of ant larvae and pupa in the diet of $M$. anchietae and $Z$. quadrifrons would be related to the damage and nest defense capacity presented by the ants. Thus, the defensive behavior of this prey category would incentive the selection of less aggressive and easily captured species (VITT \& COOPER, 1988). The captured ants would be preyed upon far from their nests, during grazing activity, minimizing the attack capacity of the colony. BERNARDO-SILVA et al. (2006) observed nomad ant species in the diet of $A$. munoai suggesting that it captures this type of prey on the soil surface.

On the other hand, there are some reports of amphisbaenians (A. alba, Amphisbaena fuliginosa Linnaeus, 1758, A. kingi and Leposternon infraorbitale (Berthold, 1859)) associated with ant nests, but probably due during the reproduction period of the species, since the eggs are frequently found in this type of environment (VEGA, 2001; ANDRADE et al., 2006). Relationships between amphisbaenians and ants are not totally, but some inferences could be made. LóPEZ \& MARTín (1994) suggest that Blanus cinereus has a chemosensory capacity of differentiating aggressive ants from potential preys, which could also be true for species that use ant nests to deposit their clutches. There are clutch records of $A$. kingi in the nests of the ants Acromyrmex Mayr, 1865 (WILLIAMS \& Wichmann, 1989) and Camponotus Mayr, 1866 (VAZ FERREIRA et al., 1970), and these ants are not an important food item for A. kingi. It was observed in the study area a clutch of the snake Taeniophallus occipitalis and a clutch of the lizard Cnemidophorus lacertoides in Acromirmex nests, indicating that anthills of this genus also served as reproductive site for other scaled reptiles.

It was observed a high trophic diversity in the diet of $A$. kingi in relation to $A$. munoai, which could be related to the larger size of the former in relation to the latter. Large sized amphisbaenians, such as Amphisbaena alba, have a more diverse diet in terms of prey size and type than species with a SVL comparatively smaller (COLLI \& ZAmBOnI, 1999). Body size is the main, but not the only, factor that determines the types of prey explored by a species (CADLE \& GREENE, 1993). However, probably due to a reduced size, $A$. munoai preys on very small specimens (BERNARDO-SILVA et al., 2006) having a less diverse diet when compared with other amphisbaenians. For example, insect larvae appear in a higher frequency and have a higher important value in the $\operatorname{diet}$ of $A$. kingi, being significant larger than the species observed in the diet of A. munoai. VEGA (2001) described insect larvae as the most numerous and frequent item in the $\operatorname{diet}$ of $A$. king $i$ in Argentina. Because their larger size in relation to other food categories, insect larvae may provide more energy, compensating the finding and ingestion costs (LÓPEZ et al., 1991).

Based on the obtained information, it is possible to verify a niche overlap between Amphisbaena munoai and Anops kingi in the study area. Even though each species presents particular biological characteristics (body size and shape of the head), they share the same substrate (fossarials in high or less degree), the same food (Isoptera), present a similar seasonal distribution, and possibly, similar daily activities. 
A similar pattern of niche overlap was observed by Martins (1994) for six species of fossorial snakes of the genus Atractus Wagler, 1828 in a forested area in Central Amazon. The author suggested that Atractus species could be segregated by body size or abundance, or the available resources in the environment were enough to support these species without competition. Anops kingi and Amphisbaena munoai are significantly different in relation to SVL size leading to higher trophic diversity and ingestion capacity of the prey in the former related to the latter. However, the difference observed between the SVL of these species, may not explain a possible segregation in gathering the main food category, Isoptera, since the size of this prey does not seem to vary and become unavailable at certain point.

Amphisbaena munoai was more frequently found than Anops kingi which could suggest that the former is more abundant in the study area. However, capture rates possibly do not reflect the actual abundance of the species, and are linked to the limitations imposed by the sampling method. By the active search method there is a tendency to capture terrestrial fossorial specimens close to the surface (e.g. partially buried under devices). VEGA (2001) cites that the presence of insect larvae in the diet of $A$. kingi may be an indicator that the species forages mainly in subterraneous galleries, different from $A$. munoai that can forage on the soil surface (BERNARDOSILVA et al., 2006).

In relation to food resource availability, studies that investigate the importance of each category in the environment are necessary. However, as suggested by MARTINS (1994) for six sintopic species of Atractus in a forested area in Central Amazon, Isoptera seems to be abundant and available enough to support two amphisbaenian species in Escudo Sul-Rio-Grandense without competition.

Limitation imposed by the fossorial habit of amphisbaenians is among the main difficulties in carrying out studies focusing on their life histories (GANs, 1978; Barros Filhos \& Valverde, 1996; Vega, 2001; Andrade $e t$ al., 2006; BERNARDO-SILVA et al., 2006). However, areas under the influence of temperate climate seem to favor the study of some species due to the easy access to the animals in their environment, as mentioned for Blanus cinereus (Vandelli, 1797) in Europe (Gil et al. 1993; LóPEZ \& MarTín, 1994, 2005; LÓPEZ \& SALVADOR, 1992, 1994; LÓPEZ et al. 1991, 1998, 2002; MARTín et al. 1990, 2000), and observed here for Amphisbaena munoai and Anops kingi in southern Brazil.

The results showed that both species present seasonal and unimodal reproductive cycles as well as distribution, and have a diverse diet, although Isoptera consists on the main food item. There were also hypotheses on seasonal distribution, use of habitat and thermal biology which may be used as objects of study in future papers.

Acknowledgments. We would like to thank Gilson N. Galera and José Carlos C. Karst for their permission to carry out the work in the Fazenda Novosares. We also thank Alfredo P. Santos Jr., Raul Maneyro, Síria L. R. Barcelos, and Fabrício Bonfiglio for their comments and help during the manuscript preparation. This work was funded by Conselho Nacional de Desenvolvimento Científico e Tecnológico (CNPq) as a scholarship granted to RLB.

\section{REFERENCES}

Aguiar, L. F. S. \& Di-Bernardo, M. 2004. Diet and feeding behavior of Helicops infrataeniatus in southern Brazil. (Serpentes, Colubridae, Xenodontinae). Studies on Neotropical Fauna and Environment 39(1):7-14.

2005. Reproduction of the water snake Helicops infrataeniatus Jan, 1865 (Colubridae) in southern Brazil. Amphibia-Reptilia 26:527-533.

Andrade, D. V.; Nascimento, L. B. \& Abe, A. S. 2006. Habits hidden underground: a review on the reproduction of the Amphisbaenia with notes on four neotropical species. Amphibia-Reptilia 27:207-217.

Azevedo-Ramos, C. \& Moutinho, P. R. S. 1994. Amphisbaenians (Reptilia: Amphisbaenidae) in nests of Atta sexdens (Hymenoptera: Formicidae) in eastern Amazonia, Brazil. Entomological News 105:183-184.

Balestrin, R. L. \& Di-Bernardo, M. 2005. Reproductive biology of Atractus reticulatus (Boulenger, 1885) (Serpentes: Colubridae) in southern Brazil. Herpetological Journal 15:195-199.

Balestrin, R. L.; Di-Bernardo, M. \& Moreno, A. G. 2007. Feeding ecology of the neotropical worm snake Atractus reticulatus in southern Brazil. Herpetological Journal 17:62-64.

Barros-Filho, J. D. \& Valverde, M. C. C. 1996. Notas sobre os Amphisbaenia (Reptilia, Squamata) da microrregião de Feira de Santana, estado da Bahia, Brasil. Sitientibus 14:57-68.

BeEbe, W. 1945. Field notes on the lizards of Kartabo, British Guiana and Caripito, Venezuela, Part 3. Teiidae, Amphisbaenidae and Scincidae. Zoologica 30:7-32.

Bernardo Silva, J. S.; Von-Mühlen, E. M.; Di-Bernardo, M. \& Ketterl, J. 2006. Feeding ecology in the small neotropical amphisbaenid Amphisbaena munoai (Amphisbaenidae) in southern Brazil. Iheringia, Série Zoologia, 96:487-489.

Bonnet, X.; Shine, R.; Naulleau, G. \& Vacher-Vallas, M. 1998. Sexual dimorphism in snakes: different reproductive roles favour different body plans. Procceedings of the Royal Society of London 265:179-183.

Cabrera, M. R. \& Merlini, H. 1990. The diet of Amphisbaena darwinii heterozonata in Argentina. Herpetological Review 21:53.

Cadle, J. E. \& Greene, H. W. 1993. Phylogenetic patterns, biogeography and the ecological structure of Neotropical snake assemblages. In: Ricklefs, R. E. \& Schluter, D. eds. Species diversity in ecological communities. Historical and geographical perspectives. Chicago, University of Chicago. p.281-293.

Cappellari, L. H.; Lema, T.; Prates JR., P. \& Rocha, C. F. D. 2007. Diet of Teius oculatus (Sauria, Teiidae) in southern Brazil (Dom Feliciano, Rio Grande do Sul). Iheringia, Série Zoologia, 97:31-35.

Civantus, E.; Martín, J. \& López, P. 2003. Fossorial life constrains microhabitat selection of the amphisbaenian Trogonophis wiegmanni. Canadian Journal Zoology 81:1839-1844.

Colli, G. R. \& Zamboni, D. S. 1999. Ecology of the Worm-Lizard Amphisbaena alba in the Cerrado of Central Brazil. Copeia 3:733-742.

Cruz-Neto, A. P. \& Abe, A. S. 1993. Diet composition of two syntopic species of neotropical amphisbaenians, Cercolophia roberti and Amphisbaena mertensii. Journal of Herpetology 27:239-240.

Di-Bernardo, M.; Borges-Martins, M.; Oliveira, R. B. \& Pontes, G. M. F. 2007. Taxocenoses de serpentes de regiões temperadas do Brasil. In: Nascimento, L. B.; Bernardes, A. T. \& Cotta, G. A. eds. Herpetologia no Brasil 2. Belo Horizonte, PUCMG p. 222-263.

Duellmann, W. E. 1978. The biology of na equatorial herpetofauna in Amazonian Equador. Miscelanous Publications of the Museum of Natural History 65:1-352.

Gadsden, H. E. \& Palacios-Orona, L. E. 1997. Seasonal dietary patterns of Mexican fringe-toed lizard (Uma paraphygas). Journal of Herpetology 31:1-9. 
Gans, C. 1978. The characteristics and affinities of the Amphisbaenia. Transactions of the Zoological Society of London 34:347-416.

2005. Checklist and bibliography of the Amphisbaena of the world. Bulletin of American Museum of Natural History 289:1-130.

Gil, M. J.; Guerrero, F. \& Pérez-Mellado, V. 1993. Observations on morphometrics and ecology in Blanus cinereus (Reptilia: Amphisbaenia). Journal of Herpetology 27:205-209.

How, R. A. \& Shine, R. 1999. Ecological traits and conservation biology of five fossorial "sand-swimming" snake species (Simoselaps: Elapidae) in south-western Australia. Journal Zoology 249:269-282.

IBGE (Instituto Brasileiro de Geografia e Estatística). 1986. Geografia do Brasil. Rio de Janeiro, Secretaria de Planejamento da Presidência e Instituto de Geografia e Estatística. 419 p.

Krebs, C. J. 2001. Ecology: The Experimental Analysis of Distribuition and Abundance. San Francisco, Benjamin Cummings. 695p.

LóPeZ, P. \& Martín, J. 1994. Responses by the amphisbaenian Blanus cinereus to chemicals from prey or potentially harmful ant species. Journal of Chemical Ecology 20:1113-1119. 2005. Intersexual differences in chemical composition of precloacal gland secretions of the amphisbaenian Blanus cinereus. Journal of Chemical Ecology 31:2913-2921.

López, P.; Martín, J. \& Cooper, W. E. 2002. Chemosensory responses to plant chemicals by the amphisbaenian Blanus cinereus. Amphibia-Reptilia 23:348-353.

López, P.; Martín, J. \& Salvador, A. 1991. Diet selection by the amphisbaenid Blanus cinereus. Herpetologica 47:210-218.

López, P. \& Salvador, A. 1992. The role of chemosensory cues in discrimination of prey odors by the amphisbaenian Blanus cinereus. Journal of Chemical Ecology 18:87-93.

1994. Tongue-flicking prior to prey attack by the amphisbaenian Blanus cinereus. Journal of Herpetology 28:502-504.

López, P.; Salvador, A. \& Martín, J. 1998. Soil temperatures, rock selection and the thermal ecology of the amphisbaenian reptile Blanus cinereus. Canadian Journal Zoology 76:673679.

Maciel, A. P.; Di-Bernardo, M.; Hartz, S. M.; Oliveira, R. B. \& Pontes, G. M. F. 2003. Seasonal and daily activity patterns of Liophis poecilogyrus (Serpentes: Colubridae) on the north coast of Rio Grande do Sul, Brazil. Amphibia-Reptilia 24:189-200.

Martín, J.; López, P. \& Barbosa, A. 2000. State-dependent and risk-sensitive escape decisions in a fossorial reptile, the amphisbaenian Blanus cinereus. Herpetological Journal 10:27-32.

Martín, J.; LóPez, P. \& SAlvador, A. 1990. Field body temperatures of the amphisbaenid lizard Blanus cinereus. AmphibiaReptilia 11:87-96.

1991. Microhabitat selection of the amphisbaenian Blanus cinereus. Copeia 1991:1142-1146.

Martins, M. 1994. História natural e ecologia de uma taxocenose de serpentes de mata na região de Manaus,
Amazônia Central, Brasil. 98p. Tese de Doutorado Ecologia. Instituto de Biologia, Universidade Estadual de Campinas. Campinas, SP. (Unpublished)

Motт, T. \& VieITes, D. R. 2009. Molecular phylogenetics reveals extreme morphological homoplasy in Brazilian worm lizards challenging current taxonomy. Molecular Phylogenetics and Evolution 51:190-200.

Nimer, E. 1989. Climatologia do Brasil. Rio de Janeiro, IBGE. $421 \mathrm{p}$.

Pianka, E. R. 1973. The structure of lizard communities. Annual Review Ecology, Evolution and Systematics 4:53-74.

Porto, M. L. 2002. Os campos sulinos, sustentabilidade e manejo. Ciência \& Ambiente 1:119-138.

Quadros, F. L. F. \& Pillar, V. 2002. Transições floresta-campo no Rio Grande do Sul Ciência \& Ambiente 1:109-118.

Rамво, B. 2000. A fisionomia do Rio Grande do Sul: ensaio de monografia natural. São Leopoldo. Ed. Unisinos. 473p. Rezende-Pinto, F. M.; Verrastro, L.; Zanotelli, J. C. \& Barata, P. C. R. 2009. Reproductive biology and sexual dimorphism in Cnemidophorus vacariensis (Sauria, Teiidae) in the grasslands of the Araucaria Plateau, southern Brazil. Iheringia, Série Zoologia, 99:82-91

Ruffato, R.; Di-Bernardo, M. \& Maschio, G. F. 2003. Dieta de Thamnodynastes strigatus (Serpentes, Colubridae) no sul do Brasil. Phyllomedusa 2:27-34.

Seigel, R. A. \& Collins, J. T. 1993. Snakes, ecology \& behavior New York, McGraw-Hill. 415p.

SHINE, R. 1977. Reproduction in Australian elapid snakes. II Female reproductive cycles. Australian Journal Zoology 25:655-666.

1988. Food Habitats and reproductive biology of small Australian snakes of genera Unechis and Suta (Elapidae). Journal of Herpetology 22:307-315.

Sinervo, B. 1993. The effect of offspring size on physiology and life history: manipulation of size using allometric engineering. Bioscience 43:210-218.

Teixeira, R. L. \& Giovanelli, M. 1999. Ecologia de Tropidurus torquatus (Sauria: Tropiduridae) da restinga de Guriri, São Mateus, ES. Revista Brasileira de Biologia 59:11-18.

Vaz-Ferreira, R.; Covelo de Zolessi, L. \& Achával, F. 1970. Ovipositión y desarrollo de ofídios y lacertílios em hormigueros de Acromyrmex. Physis 29:431-459.

VeGA, L. E. 2001. Reproductive and feeding ecology of the amphisbaenian Anops kingii in east-central Argentina. Amphibia-Reptilia 22:447-454

VitT, L. J. \& CoOPER, W. E. 1988. Feeding responses of skinks (Eumeces laticeps) to velvet ants (Dasymutilla occidentalis). Journal of Herpetology 22:485-488.

Webb, J. K.; Shine, R.; Branch, W. \& Harlow, P. S. 2000. Life underground: foods and reproductive biology of two amphisbaenian species from Southern Africa. Journal of Herpetology 34:510-516.

Williams, J. \& Wichmann, S. 1989. Nueva localidad para Anops kingii, Bell (Reptilia: Amphisbaenidae) y Philodryas aestivus (Dumeril, Bibron \& Dumeril) (Reptilia: Colubridae) en el este de la provincia de Buenos Aires. Boletín de la Asociación Herpetológica Argentina 5(1-2):12,13 